\title{
ANALISIS PELAKSANAAN PRAKTIKUM KIMIA
}

\author{
N. K.A. Damayanti ${ }^{1}$, S. Maryam², I. W. Subagia ${ }^{3}$ \\ Universitas Pendidikan Ganesha \\ e-mail: kadek.ari.damayanti@undiksha.ac.id, siti.maryam@undiksha.ac.id, \\ wayan.subagia@undiksha.ac.id
}

\begin{abstract}
ABSTRAK
Penelitian ini bertujuan untuk mendeskripsikan dan menjelaskan (1) topik/materi praktikum kimia yang dilaksanakan dalam pembelajaran kimia; (2) pelaksanaan praktikum kimia; dan (3) faktor-faktor yang memengaruhi pelaksanaan praktikum kimia di SMA Negeri 3 Singaraja. Penelitian ini merupakan penelitian kualitatif dengan menggunakan pendekatan fenomenologi. Subjek penelitian ini adalah guru kimia, kepala laboratorium, dan siswa. Teknik pengumpulan data yang digunakan adalah studi dokumen, observasi, dan wawancara. Hasil penelitian ini adalah (1) Topik/materi praktikum kimia yang direncanakan oleh guru kimia di SMA Negeri 3 Singaraja tidak semua dapat dilaksanakan. Pada kelas $X$ dilaksanakan dua topik/materi praktikum kimia dari tiga topik/materi yang direncanakan. Pada kelas XI dilaksanakan lima topik/materi praktikum kimia dari sembilan topik yang direncanakan. Pada kelas XII dilaksanakan satu topik/materi praktikum kimia dari empat topik/materi praktikum kimia yang direncanakan. (2) Pelaksanaan praktikum kimia di SMA Negeri 3 Singaraja dilaksanakan secara berkelompok dan dibimbing oleh guru kimia. (3) Faktor-faktor yang memengaruhi pelaksanaan praktikum kimia di SMA Negeri 3 Singaraja yaitu kesiapan guru dan siswa untuk melaksanakan praktikum kimia, laboratorium kimia, alat dan bahan praktikum, waktu pembelajaran, serta laboran.
\end{abstract}

Kata kunci: analisis, pelaksanaan praktikum kimia, SMA Negeri 3 Singaraja.

\begin{abstract}
This research aimed to describe and explain (1) the practicum topic conducted in chemistry learning; (2) the implementation of chemistry practicum; and (3) factors that influence the implementation of chemistry practicum in SMA Negeri 3 Singaraja. The research was a qualitative research with a phenomenology approach. The subjects of this research were chemistry teachers, laboratory head, and students. The data collection techniques used in this research were document studies, observations, and interviews. The results of this research are (1) the chemistry practicum topic planned by four teachers' chemistry in SMA Negeri 3 Singaraja is not all workable. In the tenth grade two chemistry practicum topics were hold out of three planned topics. In the eleventh grade five chemistry practicum topic were hold out of nine planned topics. In the twelfth grade hold one chemistry practicum topics of four planned topics. (2) Chemistry practicum in SMA Negeri 3 Singaraja was carried out by groups and guided by chemistry teacher. (3) Factors influencing the implementation of practicum chemistry in SMA Negeri 3
\end{abstract}


Singaraja were teachers and students' readiness, chemistry laboratory, tools and practicum material, learning time, and laboratory assistant.

Key words: analysis, implementation chemistry practicum, SMA Negeri 3 Singaraja

\section{PENDAHULUAN}

Kimia merupakan bagian dari ilmu pengetahuan alam yang diperoleh dan dikembangkan berdasarkan percobaan untuk mencari jawaban atas pertanyaan apa, mengapa, dan bagaimana tentang gejala-gejala alam khususnya yang berkaitan dengan komposisi, struktur, sifat, transformasi, dinamika, dan energetika zat (Kemendikbud, 2016). Dalam ilmu kimia terdapat dua hal yang berkaitan yaitu ilmu kimia sebagai produk dan ilmu kimia sebagai proses. Kimia sebagai produk mencakup sekumpulan pengetahuan yang terdiri atas fakta, asas, konsep, teori, serta prinsip-prinsip kimia. Kimia sebagai proses mencakup keterampilan-keterampilan dan sikap-sikap yang dimiliki oleh para ilmuan untuk memeroleh dan mengembangkan pengetahuan kimia (Ratmini, 2017).

Sesuai Peraturan Menteri Pendidikan dan Kebudayaan Nomor 20 Tahun 2016 tentang Standar Kompetensi Lulusan Pendidikan Dasar dan Menengah, sasaran pembelajaran mencakup pengembangan ranah sikap, pengetahuan, dan keterampilan yang dielaborasi untuk setiap satuan pendidikan. Ranah keterampilan (psikomotor) merupakan ranah yang berhubungan dengan aktivitas fisik seperti mengamati, menanya, mencoba, menalar, menyaji dan mencipta. Aktivitas fisik dapat diwujudkan dengan melakukan kerja ilmiah yaitu dengan melaksanakan kegiatan praktikum. Kegiatan praktikum merupakan salah satu kegiatan yang penting untuk dilaksanakan yang bertujuan untuk meningkatkan kemampuan siswa dalam bidang pengetahuan, sikap dan keterampilan. Kegiatan praktikum merupakan kegiatan aplikasi dari teori-teori yang telah dipelajari untuk memecahkan berbagai masalah melalui percobaan-percobaan di laboratrium (Wiratma dan Subagia, 2014).

Hal ini sejalan dengan hasil penelitian Mamlok (2012) menunjukkan bahwa kegiatan laboratorium memiliki peran dan manfaat penting dalam kurikulum sains. Guru kimia di Israel dalam 15 tahun terakhir telah mulai mengadakan perubahan terhadap cara mengajar pada pelajaran kimia yang dimulai dari melibatkan kegiatan praktikum dalam pembelajarannya. Penelitian ini menyatakan bahwa dengan kegiatan praktikum dapat meningkatkan pembelajaran kimia yang lebih bermakna dan lebih konseptual terhadap pemahaman peserta didik, serta hasil penelitian ini menunjukkan bahwa pelaksanaan praktikum dapat meningkatkan hasil belajar peserta didik.

Kegiatan praktikum kimia harus memerhatikan ketersediaan sarana dan prasarana penunjang praktikum. Kenyataan di lapangan menunjukkan pengelolaan sarana dan prasarana praktikum kimia belum dilakukan dengan baik. Hal ini sejalan dengan penelitian yang dilakukan oleh Laksmi, dkk. (2014) di SMA N 1 Seririt menunjukkan bahwa pengelolaan alat dan bahan praktikum belum dilakukan dengan baik, khususnya pada proses pemanfaatan, pemeliharaan, dan pemusnahan yang terlihat dari jumlah materi yang dipraktikumkan. Pada kelas $\mathrm{X}$ dari lima topik praktikum yang ditegaskan dalam kurikulum yang digunakan, hanya satu topik yang dipraktikumkan, kelas XI dari 14 topik hanya empat yang dipraktikumkan, dan kelas XII dari 10 topik hanya tiga topik yang dipraktikumkan. Penelitian ini menunjukkan bahwa pelaksanaan praktikum pada SMA Negeri 1 Seririt belum optimal dilakukan sesuai dengan kurikulum yang berlaku.

Penelitian di atas sejalan dengan penelitian Apriani (2017) menunjukkan bahwa pelaksanaan praktikum di SMA Negeri 2 Singaraja pada tahun ajaran 2017/2018 belum dilaksanakan dengan optimal. Tidak semua jenis praktikum yang terdapat pada silabus 
dilaksanakan sesuai dengan perencanaan awal yang dibuat oleh guru. Faktor yang memengaruhi kegiatan praktikum tidak dapat dilaksanakan karena kekurangan waktu, dimana guru merancang waktu pelaksanaan praktikum sekitar 2 jam, tetapi dikelas dapat menghabiskan waktu 3 jam sehingga tidak sesuai dengan perencanaan awal yang telah dibuat. Faktor lain yang ditemui peneliti adalah kurangnya alat dan bahan untuk melaksanakan kegiatan praktikum.

Sejalan dengan itu, penelitian yang dilakukan oleh Ariani (2016) menemukan bahwa pelaksanaan praktikum kimia di SMA Negeri 1 dan 2 Semarapura pada tahun ajaran 2015/2016 belum sesuai dengan kompetensi dasar pada silabus Kurikulum 2013. Hal ini disebabkan oleh beberapa kendala yang dihadapi dalam melaksanakan praktikum kimia yaitu keterbatasan alat dan bahan kimia, kurangnya waktu pelaksanaan praktikum, keterbatasan ruang laboratorium, kurangnya keterampilan, dan pemahaman siswa dalam praktikum. Usaha yang dilakukan guru untuk mengatasi masalah yang dihadapi yaitu melakukan demonstrasi dan mengganti alat serta bahan kimia dengan fungsi dan sifat yang sama, menerapkan sistem moving class, memberikan penjelasan konsep dan latihan soal serta berdiskusi dengan berbantuan media pembelajaran, dan membimbing siswa untuk memecahkan masalah yang dihadapi.

Pelaksanaan jumlah praktikum yang rendah baik kelas X, XI dan XII disebabkan oleh beberapa faktor. Faktor pelaksanaan praktikum salah satunya adalah keterbatasan alat dan bahan praktikum sehingga beberapa topik praktikum kimia belum terlaksana secara optimal sesuai dengan silabus. Penelitian yang dilakukan Samiasih, dkk. (2013) menunjukkan bahwa persentase ketersediaan jenis ruang dan fasilitas umum yang sesuai standar adalah $53 \%$ (kategori kurang), persentase ketersediaan jumlah alat yang memenuhi standar adalah $45 \%$ (kategori kurang), dan persentase ketersediaan jumlah bahan kimia yang memenuhi standar adalah $48 \%$ (kategori kurang).

Hasil-hasil penelitian yang dipaparkan di atas menunjukkan bahwa pelaksanaan praktikum yang dilaksanakan dibeberapa sekolah kurang optimal. Hal tersebut juga terjadi di SMA Negeri 3 Singaraja. Hasil-hasil penelitian yang dipaparkan di atas menunjukkan bahwa pelaksanaan praktikum yang dilaksanakan dibeberapa sekolah kurang optimal. Hal tersebut juga terjadi di SMA Negeri 3 Singaraja. SMA Negeri 3 Singaraja adalah salah satu sekolah negeri beralamat di Jalan Pulau Natuna Penarukan Singaraja. SMA Negeri 3 Singaraja merupakan sekolah yang terakreditasi A di kota Singaraja yang telah menggunakan Kurikulum 2013. Sekolah ini memiliki 3 guru kimia yang sudah tersertifikasi dan 1 guru kimia yang belum tersertifikasi.

Berdasarkan studi pendahuluan pada tanggal 2 November 2018 yang dilakukan di SMA Negeri 3 Singaraja menunjukkan bahwa masih ada permasalahan yang dijumpai yaitu, saat penyiapan alat dan bahan, guru kimia yang menyiapkan alat dan bahan praktikum karena tidak ada laboran, tidak semua topik/materi praktikum kimia yang direncanakan dapat dilaksanakan, kurangnya alat dan bahan untuk melaksanakan praktikum, dan ruang laboratorium yang terdapat di SMA Negeri 3 Singaraja digunakan sebagai ruang kelas untuk ruang belajar sehingga untuk melakukan praktikum harus dilakukan di kelas dengan membawa alat dan bahan yang akan digunakan praktikum ke dalam kelas. Hal ini menyebabkan pelaksanaan praktikum kimia yang dilakukan di SMA Negeri 3 Singaraja belum dilaksanakan secara optimal.

Informasi hasil studi pendahuluan di atas perlu dikaji lebih dalam lagi. Oleh karena itu, penelitian mengenai pelaksanaan praktikum kimia di SMA Negeri 3 Singaraja sangat perlu dilaksanakan. Penelitian ini dilaksanakan pada semester genap tahun ajaran 2018/2019 dengan memfokuskan pada tiga permasalahan, yaitu (1) topik/materi praktikum kimia yang direncanakan dan dilaksanakan di SMA Negeri 3 Singaraja (2) pelaksanaan praktikum kimia, dan (3) faktor-faktor yang memengaruhi pelaksanaan praktikum kimia di SMA Negeri 3 Singaraja.

Penelitian ini bertujuan untuk (1) mendeskripsikan dan menjelaskan topik/materi praktikum kimia yang direncanakan dan dilaksanakan di SMA Negeri 3 Singaraja; (2) mendeskripsikan dan menjelaskan pelaksanaan praktikum kimia di SMA Negeri 3 Singaraja; dan (3) mendeskripsikan 
dan menjelaskan faktor-faktor yang memengaruhi pelaksanaan praktikum kimia di SMA Negeri 3 Singaraja.

\section{METODE}

Penelitian ini merupakan penelitian kualitatif dengan menggunakan pendekatan fenomenologi. Subjek penelitian ini adalah empat guru kimia, satu kepala laboratorium dan siswa kelas X, XI, dan XII di SMA Negeri 3 Singaraja. Teknik pengumpulan data yang digunakan adalah studi dokumen, observasi, dan wawancara. Teknik studi dokumen dilakukan untuk memeroleh data berupa topik/materi praktikum kimia yang direncanakan untuk kelas X, XI, dan XII, dan topik/materi praktikum kimia yang dilaksanakan tahun pelajaran 2018/2019 di SMA Negeri 3 Singaraja. Observasi digunakan untuk mendapatkan data terkait proses pelaksanaan praktikum kimia secara langsung. Wawancara digunakan untuk memperdalam data yang sudah didapat melalui studi dokumen dan observasi.

Analisis data dalam penelitian ini meliputi tiga tahap yaitu analisis sebelum di lapangan, selama di lapangan dan setelah di lapangan. Analisis setelah di lapangan dilakukan tiga analisis, yaitu: reduksi data, penyajian data, dan penarikan kesimpulan. Teknik pemeriksaan keabsahan data dalam penelitian ini yaitu triangulasi dan member check.

\section{HASIL DAN PEMBAHASAN}

1) Topik/materi Praktikum Kimia

Topik/materi praktikum kimia yang direncanakan dapat diperoleh dari studi dokumen silabus mata pelajaran kimia dan RPP yang digunakan guru kimia kelas X, XI, dan XII. Berdasarkan studi dokumen silabus mata pelajaran kimia jumlah topik/materi praktikum kimia untuk kelas $\mathrm{X}$ terdapat lima topik/materi praktikum kimia, untuk kelas XI terdapat sembilan topik/materi praktikum kimia, dan untuk kelas XII terdapat enam topik/materi praktikum kimia. Selain itu, berdasarkan studi dokumen RPP ditemukan untuk kelas $X$ terdapat tiga topik/materi praktikum kimia yang direncanakan, untuk kelas XI terdapat sembilan topik/materi praktikum kimia yang direncanakan, dan untuk kelas XII terdapat lima topik/materi praktikum kimia yang direncanakan.

Topik/materi praktikum kimia sesuai dengan silabus mata pelajaran kimia yang digunakan guru kimia di SMA Negeri 3 Singaraja di kelas $X$ yaitu (1) Metode ilmiah, hakikat ilmu kimia, keselamatan dan keamanan kimia di laboratorium, peran kimia dalam kehidupan. (2) Ikatan Kimia, bentuk molekul, dan interaksi antarmolekul, (3) Larutan elektrolit dan nonelektrolit. (4) Reaksi reduksi dan oksidasi serta tata nama senyawa. (5) Hukum-hukum dasar kimia dan stoikiometri. Topik/materi praktikum kimia sesuai silabus mata pelajaran kimia di kelas XI yaitu (1) Termokimia, (2) Laju reaksi dan faktor-faktor yang mempengaruhi, (3) Kesetimbangan kimia dan pergeseran kesetimbangan, (4) Asam dan basa, (5) Kesetimbangan ion dan pH larutan garam, (6) Larutan penyangga, (7) Titrasi, (8) Kesetimbangan kelarutan, (9) Sistem koloid. Topik/materi praktikum kimia sesuai silabus mata pelajaran kimia di kelas XII yaitu (1) Sifat koligatif larutan, (2) Redoks dan sel elektrolisis, (3) Kimia unsur, (4) Struktur, tata nama, sifat, isomer, identifikasi dan kegunaan senyawa: haloalkana, amina, alkanol dan alkoksi alkana, alkanal dan alkanon, asam alkanoat dan alkil alkanoat, (5) Struktur, tata nama, sifat, penggunaan dan penggolongan makromolekul.

Topik/materi praktikum kimia yang direncanakan guru kimia di SMA Negeri 3 Singaraja di kelas $X$ yaitu (1) Ikatan kimia, bentuk molekul, dan interaksi antarmolekul, (2) Larutan elektrolit dan nonelektrolit, (3) Reaksi reduksi dan oksidasi. Topik/materi praktikum kimia yang direncanakan di kelas XI yaitu (1) Termokimia, (2) Laju reaksi dan faktor-faktor yang mempengaruhi, (3) Kesetimbangan kimia dan pergeseran kesetimbangan, (4) Asam dan basa, (5) Kesetimbangan ion dan $\mathrm{pH}$ larutan garam, (6) Larutan penyangga, (7) Titrasi, (8) Kesetimbangan kelarutan, (9) Sistem koloid. Topik/materi praktikum kimia yang direncanakan di kelas XI yaitu (1) Sifat koligatif larutan, (2) Redoks dan sel elektrokimia, (3) Kimia unsur. 
GK 1 pada kelas $X$ merencanakan tiga topik/materi praktikum kimia tetapi hanya dua topik/materi yang terlaksana. GK 2 merencanakan tiga topik/materi praktikum kimia tetapi tidak ada topik/materi praktikum kimia yang dilaksanakan. GK 3 merencanakan sebelas topik/materi praktikum kimia yang direncanakan tetapi hanya lima topik/materi praktikum kimia yang dilaksanakan. GK 1 dan GK 4 pada kelas XII merencanakan empat topik/materi praktikum kimia tetapi hanya satu topik/materi kimia yang dilaksanakan.

Topik/materi praktikum kimia yang dilaksanakan diperoleh melalui studi dokumen berupa jurnal yang terdapat di kelas dan laboratorium. Pada semester ganjil topik/materi praktikum kimia yang dilaksanakan kelas $\mathrm{X}$, yakni hakikat ilmu kimia, tetapi tidak sesuai dengan perencanaan yang dibuat sebelumnya. Pada silabus K13 seharusnya dilakukan praktikum ilmiah misalnya menentukan variabel yang memengaruhi kelarutan gula dan air, tetapi diganti dengan mengobservasi laboratorium kimia.

Pada semester genap, topik/materi praktikum kimia yang direncanakan dan dilaksanakan praktikum, yaitu larutan elektrolit dan nonelektrolit dan reaksi reduksi dan oksidasi. Pada silabus mata pelajaran kimia terdapat tiga praktikum, tetapi direncanakan hanya dua topik/materi praktikum yang direncanakan dan dilaksanakan.

Pada semester ganjil topik/materi praktikum kimia kelas XI yang direncanakan dan dilaksanakan yakni, termokimia, laju reaksi dan faktor-faktor yang memengaruhi, kesetimbangan kimia. Pada semester genap topik/materi yang dilaksanakan asam basa dan larutan penyangga.

Pada semester ganjil, hanya satu topik/materi praktikum kimia yang dilaksanakan pada kelas XII, yaitu redoks dan sel elektrokimia. Hal ini tidak sesuai dengan perencanaan awal dan silabus mata pelajaran kimia kurikulum 2013. Pada kelas XII semester genap, GK 1 dan GK 4 tidak merencanakan dan melaksanakan praktikum. Hal ini dikarenakan pada kelas XII hanya memfokuskan pada materi dan pembahasan soal-soal yang diperkirakan keluar pada saat ujian agar siswa siap untuk menghadapi USBN dan UNBK.

\section{2) Pelaksanaan Praktikum Kimia}

Data mengenai pelaksanaan praktikum kimia di SMA Negeri 3 Singaraja diperoleh melalui observasi langsung proses pembelajaran kimia dan melalui wawancara mendalam dengan guru kimia, kepala laboratorium dan siswa.

Observasi pelaksanaan praktikum kimia di kelas $X$ dilaksanakan sebanyak dua kali untuk dua kelas X. Observasi pelaksanaan praktikum kimia di kelas XI dilaksanakan sebanyak dua kali untuk setiap kelas. Dengan demikian, observasi pelaksanaan praktikum kimia dilaksanakan sebanyak sepuluh kali.

Secara umum pelaksanaan praktikum kimia di SMA Negeri 3 Singaraja yang dilaksanakan oleh GK 1, GK 3, GK 4 dilakukan secara berkelompok, dan hanya diawasi oleh guru kimia. Pelaksanaan praktikum kimia di SMA Negeri 3 Singaraja untuk setiap kelasnya dilakukan secara berkelompok. Anggota kelompok masing-masing 4-5 atau 5-6 siswa sesuai dengan jumlah keseluruhan siswa di masing-masing kelas. Selain itu, Pelaksanaan praktikum kimia di SMA Negeri 3 Singaraja hanya diawasi dan dibimbing oleh guru kimia yang mengajar pada saat itu. Hal ini dikarenakan tidak adanya laboran di SMA Negeri 3 Singaraja. Selain itu, kepala laboratorium tidak ikut mengawasi dan membimbing siswa pada saat melaksanaan praktikum kimia.

Hal ini sejalan dengan penelitian Samiasih (2013) menunjukkan bahwa praktikum dilakukan sesuai dengan jumlah siswa tiap kelompok 4-5 orang. Pelaksanaan praktikum dilaksanakan secara bergantian sehingga setiap kelompok dapat menggunakan alat dan bahan yang jumlahnya terbatas.

Secara spesifik pelaksanaan praktikum kimia di SMA Negeri 3 Singaraja memiliki perbedaan antar topik/materi yang dipraktikumkan. Perbedaannya yakni tempat pelaksanaan praktikum kimia dan tahapan pelaksanaan praktikum kimia. Tempat pelaksanaan praktikum kelas X MIPA 3 
berbeda dengan kelas X MIPA 4 dan XI MIPA. Untuk kelas X MIPA 3 pelaksanaan praktikum dilakukan di kelas karena laboratorium kimia yang ada di SMA Negeri 3 Singaraja digunakan sebagai ruang kelas. Sedangkan untuk kelas X MIPA 4 dan XI MIPA dilaksanakan di laboratorium. Pelaksanaan praktikum kimia yang dilaksanakan pada X MIPA 3 tidak sesuai dengan Permendiknas Nomor 24 Tahun 2007.

Tahapan pelaksanaan praktikum kimia yang dilakukan oleh GK1 dan GK 3 pada materi yang berbeda dimasing-masing kelas tahapan pelaksanannya berbeda. Menurut Permendikbud Nomor 22 Tahun 2016, tahapan pelaksanaan meliputi kegiatan pendahuluan, inti, dan penutup. Dalam pelaksanaan pembelajaran yang memanfaatkan laboratorium, tahap pelaksanaannya tidak jauh berbeda dengan tahapan kegiatan pembelajaran di kelas.

Tahapan pelaksanaan praktikum kimia yang dilaksanakan oleh GK 1 pada topik larutan elektrolit dan nonelektrolit dan reaksi reduksi oksidasi berbeda. Pada praktikum larutan elektrolit dan nonelektrolit terdiri dari tiga tahapan yaitu kegiatan pendahuluan, inti dan penutup. Sedangkan pada topik reaksi reduksi oksidasi terdiri dari dua tahapan yaitu kegiatan pendahuluan dan inti.

Berdasarkan pemaparan di atas, dapat disimpulkan bahwa GK 1 dalam melaksanakan praktikum kimia topik/materi larutan elektrolit dan nonelektrolit sudah sesuai dengan tahapan pelaksanaan pembelajaran yang ditetapkan pada Permendikbud Nomor 22 Tahun 2016 yaitu terdapat kegiatan pendahuluan, inti, dan penutup. Sedangkan tahapan pelaksanaan praktikum kimia topik/materi reaksi reduksi oksidasi hanya ada kegiatan pendahuluan dan inti saja. Hal ini tidak sesuai dengan Permendikbud Nomor 22 Tahun 2016.

Tahapan pelaksanaan praktikum kimia yang dilaksanakan oleh GK 3 pada topik asam basa dan larutan penyangga berbeda. Pada praktikum larutan asam basa terdiri dari tiga tahapan yaitu kegiatan pendahuluan, inti dan penutup. Sedangkan pada topik larutan penyangga terdiri dari dua tahapan yaitu kegiatan pendahuluan dan inti.

Berdasarkan pemaparan di atas dapat disimpulkan bahwa GK 3 dalam melaksanaan praktikum kimia pada topik asam basa sudah sesuai dengan tahapan kegiatan pembelajaran berdasarkan Permendikbud Nomor 22 Tahun 2016, yaitu adanya kegiatan pendahuluan, inti dan penutup. Sedangkan pada topik larutan penyangga, GK 3 hanya melaksanakan kegiatan pendahuluan dan inti. Hal ini tidak sesuai dengan Permendikbud Nomor 22 Tahun 2016.

3) Faktor-faktor yang memengaruhi pelaksanaan praktikum kimia.

Faktor-faktor yang memengaruhi pelaksanaan praktikum kimia terdiri dari faktor pendukung dan faktor penghambat. Faktor pendukung pelaksanaan praktikum kimia yaitu kesiapan guru dan siswa untuk melaksanakan kegiatan praktikum. Faktor penghambat pelaksanaan praktikum kimia yaitu; (1) ruang laboratorium kimia digunakan sebagai ruang kelas; (2) keterbatasan alat dan bahan; (3) kekurangan waktu; serta (4) tidak adanya laboran.

Kesiapan guru dan siswa sangat mendukung jalannya pelaksanaan praktikum kimia. Kesiapan siswa sangat memengaruhi pelaksanaan praktikum kimia. Rasa antusias siswa dalam melaksanakan praktikum kimia sangat tinggi sehingga sangat pendukung jalannya pelaksanaan praktikum. Selain itu, rasa ingin tahu siswa terhadap hal-hal baru sangat tinggi, sehingga kesiapan siswa dalam melaksanakan praktikum kimia merupakan faktor pendukung dalam pelaksanaan praktikum kimia. Selain itu, kesiapan guru sangat memengaruhi pelaksanaan praktikum kimia. Kesiapan guru untuk melaksanakan kegiatan praktikum sangat diperlukan dalam melaksanakan kegiatan praktikum. Kesiapan guru ini dengan senantiasa dapat berkreasi untuk merancang kegiatan praktikum kimia meskipun adanya keterbatasan sarana dan prasarana laboratorium.

Penggunaan laboratorium kimia sebagai ruang kelas menjadi salah satu faktor penghambat jalannya praktikum kimia. Hal ini menyebabkan praktikum kimia dilaksanakan di ruang kelas atau dilakukan penukaran kelas dengan kelas yang menggunakan laboratorium kimia sebagai ruang kelas. Berdasarkan fungsinya, laboratorium kimia tidak seharusnya digunakan sebagai ruang 
kelas. Hal tercantum dalam Permendiknas Nomor 24 Tahun 2007 tentang sarana dan prasarana bahwa ruang kelas adalah tempat pembelajaran teori dan praktik yang tidak memerlukan peralatan khusus, sedangkan laboratorium kimia digunakan untuk pembelajaran dengan praktik yang memerlukan peralatan khusus. Hal ini menunjukkan bahwa penggunaan laboratorium sebagai ruang kelas dapat menghambat pelaksanaan praktikum kimia di SMA Negeri 3 Singaraja.

Keterbatasan alat dan bahan menyebabkan pelaksanaan praktikum dibeberapa topik/materi praktikum kimia tidak terlaksana. Hal ini menjadi salah satu faktor penghambat jalannya praktikum. Namun, Keterbatasan alat dan bahan ini dapat diatasi guru dengan melaksanakan praktikum kimia secara berkelompok dan bergiliran. Hal ini senada dengan penelitian Samiasih, dkk. (2013) dan Faika (2011). Menurut penelitian Samiasih, dkk. (2013) bahwa ketersediaan alat dan bahan akan menentukan banyak sedikitnya jumlah praktikum yang dapat dilakukan. Faika (2011) menyatakan bahwa pelaksanaan praktikum di laboratorium sangat bergantung pada ketersediaan alat dan bahan yang akan digunakan dalam pelaksanaan praktikum.

Kekurangan waktu dalam melaksanakan praktikum menjadi faktor penghambat jalannya praktikum kimia. Kekurangan waktu ini disebabkan karena waktu yang dialokasikan pada kurikulum tidak memerhatian kondisi riil di lapangan. Beberapa pelaksanaan praktikum tidak berjalan dengan optimal dikarenakan kekurangan waktu dalam melaksanakan praktikum, sehingga pengetahuan siswa dalam melaksanakan praktikum sangat minim.

Faktor penghambat lainnya adalah tidak adanya laboran khusus kimia. Menurut Permendiknas Nomor 26 Tahun 2008 bahwa salah satu tugas laboran adalah menyiapkan peralatan sesuai dengan penuntun praktikum dan melayani peserta didik dalam melaksanakan praktikum. Hal ini menandakan bahwa laboran sangat membantu guru dalam menyiapkan alat dan bahan praktikum, merapikan kembali alat pada tempatnya, tetapi di SMA Negeri 3 Singaraja tidak adanya laboran sehingga setiap guru harus menyiapkan alat dan bahan dan merapikan kembali sesudah menggunakan alat. Tidak adanya laboran merupakan salah satu penghambat pelaksanaan praktikum.

\section{SIMPULAN DAN SARAN}

Berdasarkan hasil dan pembahasan yang telah dipaparkan di atas, dapat disimpulkan sebagai berikut.

1) Topik/materi praktikum kimia yang direncanakan oleh empat guru kimia di SMA Negeri 3 Singaraja tidak semua dapat dilaksanakan. Untuk kelas $X$ hanya dua topik/materi praktikum kimia yang dilaksanakan dari tiga topik/materi yang direncanakan. Pada kelas $\mathrm{X}$ topik/materi praktikum kimia yang dilaksanakan yaitu larutan elektrolit dan nonelektrolit, dan reaksi reduksi dan oksidasi. Untuk kelas XI hanya lima topik/materi praktikum kimia dilaksanakan dari sembilan topik yang direncanakan. Topik/materi praktikum kimia kelas XI yang dilaksanakan yakni; (1) termokimia; (2) laju reaksi dan faktor-faktor yang mempengaruhi; (3) kesetimbangan kimia dan pergeseran kesetimbangan kimia; (4) asam dan basa; (5) larutan penyangga. Untuk kelas XII hanya satu topik/materi praktikum kimia dilaksanakan dari empat topik/materi praktikum kimia yang direncanakan. Topik/materi praktikum kimia kelas XII yang dilaksanakan yakni redoks dan elektrokimia.

2) Pelaksanaan praktikum kimia di SMA Negeri 3 Singaraja secara umum dilaksanakan secara berkelompok. Anggota kelompok terdiri dari 4-5 atau 5-6 siswa. Selain itu pelaksanaan praktikum kimia di SMA Negeri 3 Singaraja hanya diawasi dan dibimbing oleh guru kimia yang sedang mengajar. Secara spesifik pelaksanaan praktikum kimia di SMA Ngeri 3 Singaraja memiliki perbedaan diantaranya, tempat pelaksanaan praktikum kimia dan tahapan pelaksanaan praktikum kimia. Untuk kelas X MIPA 4 dan XI MIPA praktikum kimia dilaksanakan di laboratorium kimia, sedangkan untuk kelas X MIPA 3 pelaksanaan praktikum dilakukan di kelas. Tahapan pelaksanaan praktikum kimia Untuk kelas $X$ topik/materi larutan 
elektrolit dan nonelektrolit tahap pelaksanaannya terdiri dari kegiatan awal, inti, dan akhir. Sedangkan pada topik/materi reaksi reduksi oksidasi tahap pelaksanaannya hanya terdiri dari kegiatan awal dan inti. Untuk kelas kelas XI topik/materi asam dan basa tahap pelaksanaannya terdiri dari kegiatan awal, inti, dan akhir. Sedangkan pada topik/materi larutan penyangga tahap pelaksanaannya hanya terdiri dari kegiatan awal dan inti.

3) Faktor-faktor yang memengaruhi pelaksanaan praktikum kimia di SMA Negeri 3 Singaraja sebagai berikut.

a. Faktor pendukung pelaksanaan praktikum kimia yakni kesiapan guru dan siswa untuk melaksanakan praktikum kimia.

b. Faktor yang menghambat pelaksanaan praktikum kimia, yakni laboratorium kimia yang digunakan sebagai ruang kelas, keterbatasan alat dan bahan, keterbatasan waktu, serta tidak adanya laboran.

Berdasarkan hasil penelitian yang diperoleh, disampaikan saran sebagai berikut.

1. Guru hendaknya mengelola waktu pelajaran dengan baik sehingga pelaksanaan praktikum dapat berjalan dengan optimal dan sesuai dengan kompetensi dasar yang ada dalam silabus mata pelajaran kimia.

2. Guru hendaknya mengatasi keterbatasan alat dan bahan dengan memodifikasi alat serta mengganti bahan sehingga pelaksanaan praktikum dapat dilaksanakan.

3. Pihak sekolah disarankan untuk mengembalikan fungsi laboratorium kimia agar fungsi laboratorium kimia berfungsi sesuai dengan Permendiknas Nomor 24 Tahun 2007.

4. Bagi pemerintah, disarankan agar dapat mewujudkan pemenuhan standar kuantitas maupun kualitas sarana dan prasarana laboratorium kimia sebagai daya dukung pelaksanaan praktikum kimia.

\section{DAFTAR RUJUKAN}

Apriani, N. K. T. 2017. Analisis Pelaksanaan Praktikum Kimia di SMA Negeri 2 Singaraja Tahun Ajaran 2017/2018. Skripsi (Tidak Diterbitkan). Jurusan Pendidikan Kimia, Fakultas Matematika Dan IImu Pengetahuan Alam, Universitas Pendidikan Ganesha.

Ariani, N. K. 2016. Analisis Pelaksanaan Praktikum Kimia Kelas XI di SMA Negeri 1 dan 2 Semarapura Pada Tahun Ajaran 2015/2016. Skripsi (Tidak Diterbitkan). Jurusan Pendidikan Kimia, Fakultas Matematika Dan IImu Pengetahuan Alam, Universitas Pendidikan Ganesha.

Faika, S dan S. Side. 2011. Analisis Kesulitan Mahasiswa dalam Perkuliahan dan Praktikum Kimia Dasar di Jurusan Kimia FMIPA Universitas Negeri Makassar. Jurnal Chemica, Vol. 12, No. 2 (tanpa hlm).

Laksmi, I. G. A., I. G. L. Wiratma, dan I.W. Subagia. 2014. Equipments and Materials Management of Chemistry Laboratory at SMAN 1 Seririt. E-Journal Kimia Visvitalis Universitas Pendidikan Ganesha, Vol. 2, No. 1 (hlm. 48-55).

Mamlok-Naaman, R. N. 2012. Laboratory Activities in Israel. Eurasia Journal of Mathematics, Science and Technology Education, Vol. 13, No. 9 (hlm. 49-57).

Peraturan Menteri Pendidikan dan Kebudayaan Nomor 20 Tahun 2016 tentang Standar Kompetensi Lulusan Pendidikan Dasar dan Menengah. Jakarta: Departemen Pendidikan dan Kebudayaan.

Peraturan Menteri Pendidikan dan Kebudayaan Nomor 22 Tahun 2016 tentang Proses Pendidkan Dasar dan Menengah. Jakarta: Departemen Pendidikan dan Kebudayaan. 
Peraturan Menteri Pendidikan Nasional Republik Indonesia Nomor 24 Tahun 2007 tentang Standar Sarana dan Prasarana untuk Sekolah/Madrasah. Jakarta: Departemen Pendidikan Nasional.

Peraturan Menteri Pendidikan Nasional Republik Indonesia Nomor 26 Tahun 2008 tentang Standar Tenaga Laboratorium untuk Sekolah/Madrasah. Jakarta: Departemen Pendidikan Nasional.

Ratmini, W. S. 2017. The Implementation of Chemistry Practicum at SMA Laboratorium Undiksha Singaraja in the School Year 2016/2017, Jurnal Pendidikan Indonesia. Vol. 6, No. 2 (hlm. 242-254).

Samiasih, L., I. W. Muderawan, dan I. W. Karyasa. 2013. Analisis Standar Laboratorium Kimia dan Efektifitasnya Terhadap Capaian Kompetensi Adatif di SMK Negeri 2 Negara. E-Journal Program Pascasarjana Universitas Pendidikan Ganesha, Vol. 3 (tanpa hlm).

Wiratma, I. G. L., dan I. W. Subagia. 2014. Pengelolaan Laboratorium Kimia Pada SMA Negeri di Kota Singaraja: (Acuan Pengembangan Model Panduan Pengelolaan Laboratorium Kimia Berbasis Kearifan Lokal Tri Sakti), Jurnal Pendidikan Nasional. Vol. 3, No. 2 (hlm. 425-436). 